\title{
Pengelolaan tuberkulosis paru melalui peran pos TB di Desa Teluk Paman Kecamatan Kampar Kiri
}

\author{
Zahtamal*, Tuti Restuastuti, Fifia Chandra, Sri Melati Munir, dan Ridha Restila \\ Universitas Riau \\ * afisifeizah@gmail.com
}

\begin{abstract}
Abstrak. Penyakit Tuberkulosis (TB) masih menjadi ancaman bagi masyarakat di Desa Teluk Paman, Kecamatan Kampar Kiri, Kabupaten Kampar. Selain itu, belum optimalnya penanggulangan TB melalui upaya pemberdayaan masyarakat oleh pemerintah dan tenaga kesehatan. Hal ini ditandai dengan belum adanya "Pos TB Desa" dan kader TB yang dapat membantu pengelolaan TB berbasis masyarakat di desa tersebut. Strategi memberdayakan masyarakat dapat dilakukan dengan berbagai cara, antara lain advokasi, bina suasana dan gerakan masyarakat. Tujuan pengabdian kepada masyarakat ini adalah mengkaji implementasi pemberdayaan masyarakat dalam pencegahan dan penanggulangan TB (P2TB) serta melihat efektifvitas advokasi dan pelatihan dalam mewujudkan kader yang terberdayakan dalam P2TB. Metode pemberdayaan yang dilakukan adalah advokasi, membentuk wadah "pos TB desa", jejaring pengendalian TB desa, pelatihan dengan metode ceramah tanya jawab dikombinasi dengan simulasi dan penggunaan berbagai media edukasi. Kegiatan ini telah memberikan banyak manfaat. Masyarakat telah dapat memanfaatkan Pos TB Desa yang telah tersedia. Kegiatan ini membantu Dinas Kesehatan dan pemerintah daerah setempat dalam mencegah dan mengendalikan kasus TB. Kegiatan ini juga meningkatkan pengetahuan dan keterampilan kader Pos TB desa untuk membantu mencegah dan mengendalikan TB paru.
\end{abstract}

Kata kunci: keterampilan kader; pos TB desa; simulasi peran kader TB; tuberkulosis

\begin{abstract}
Tuberculosis (TB) is still a threat to the community in Teluk Paman Village, Kampar Kiri District, Kampar Regency. In addition, it is not yet optimal for community empowerment by the government and health workers. This is indicated by the absence of a "Pos TB Desa" and TB cadres who can assist community-based TB management in the village. The strategy of empowering the community can be done in various ways, including advocacy, community development and community movements. The purpose of this community service was to examine the implementation of community empowerment in TB prevention and control and to see the effectiveness of advocacy and training in realizing empowered cadres. The empowerment method was advocacy, forming a "Pos TB Desa" and village TB control network, training with question and answer lecture methods combined with simulations and using various educational media. This activity has provided many benefits. The community has been able to utilize the TB Village Post that is already available. This activity helps the Health Office and local government in preventing and controlling TB cases. This activity also increases the knowledge and skills of village TB Post cadres to help prevent and control TB.
\end{abstract}

Keywords: cadre skills; simulation of TB cadre role; tuberculosis; village TB post

To cite this article: Zahtamal, T. Restuastuti, F. Chandra, S. M. Munir, \& R. Restila. 2019. Pengelolaan tuberkulosis paru melalui peran pos TB di Desa Teluk Paman Kecamatan Kampar Kiri. Unri Conference Series: Community Engagement 1: 420-427 https://doi.org/10.31258/unricsce.1.420-427

(C) 2019 Authors

Peer-review under responsibility of the organizing committee of Seminar Nasional Pemberdayaan Masyarakat 2019 


\section{PENDAHULUAN}

Tuberkulosis (TB) merupakan salah satu penyakit menular yang disebabkan oleh infeksi mikroorganisme Mycobacterium tuberculosis. Proses infeksi oleh mikroorganisme Mycobacterium tuberculosis sebagian besar menyerang paru, tetapi dapat juga mengenai organ tubuh lainya. Penularan TB terjadi melalui udara pada saat pasien TB batuk atau bersin yang menghasilkan percikan (droplet) yang mengandung mikroorganisme. Setiap pasien batuk dapat menghasilkan sekitar 3000 percikan dahak (Kemenkes RI, 2011).

World Health Organization (WHO) memperkirakan sepertiga penduduk dunia tertinfeksi Mycobacterium tuberculosis. Data WHO diketahui bahwa pada tahun 2000- 2015, sebanyak 49 juta orang di dunia telah menderita TB. Pada tahun 2015 ditemukan 10,4 juta kasus TB baru di dunia, dan diketahui sebanyak 1,4 juta orang meninggal karena TB (WHO, 2016). Kasus TB di Provinsi Riau pada tahun 2014 terdapat 4161 kasus dan meningkat menjadi 4405 pada tahun 2015 (Dinkes Prov Riau, 2015). Kasus TB BTA Positif pada tahun 2014 di Kabupaten Kampar berjumlah 302 kasus (Dinkes Kab. Kampar, 2014).

Sekitar 75\% pasien TB adalah kelompok usia paling produktif secara ekonomis (15-50 tahun). Kelompok usia terbanyak yang terkena penyakit TB adalah usia 25-34 tahun (18,65\%) (Kemenkes RI, 2014). Selain merugikan secara ekonomis, TB juga memberikan dampak sosial berupa stigma bahkan dikucilkan dari masyarakat. Data WHO Global Tuberculosis Report 2016, Indonesia menempati posisi ke dua dengan beban TBC tertinggi di dunia setelah India (Kemenkes RI, 2018). Resistensi obat pada pengobatan TB juga menjadi masalah kesehatan masyarakat yang penting di sejumlah Negara (Fauci dan NIAID Tuberculosis Working Group, 2008). Penyebabnya dapat berasal dari penyedia pelayanan kesehatan, ketidakpatuhan dan kondisi pasien, serta penyediaan atau kualitas obat yang tidak adekuat (Burhan, 2010; Fauci dan NIAID Tuberculosis Working Group, 2008).

Laporan pengendalian TB Provinsi Riau tahun 2013 menunjukkan bahwa kasus Tuberkulosis yang berhasil diobati (succes rate) belum mencapai target nasional 85\%. Dengan kondisi ini, dikawatirkan muncul kasus TB-MDR yang sulit untuk diobati (Dinkes Prov. Riau, 2015). Di kabupaten Kampar pada tahun 2014 ditemui kasus TB MDR sebanyak 7 orang (Dinkes Kab. Kampar, 2014). Selain succes rate yang rendah, TB MDR, dan Total DR, case detection rate (CDR) kasus TB di Indonesia juga masih rendah. Adapun target standar global pencapaian CDR pada tahun 2015 adalah sebesar 70\%. Tetapi Indonesia belum dapat mencapai target tersebut, yaitu sebesar $57,1 \%$. Indonesia juga mengalami penurunan target keberhasilan pengobatan TB pada tahun 2015, yaitu 85\%. Provinsi Riau hanya mencapai angka keberhasilan pengobatan sebesar 79,6\% (Kemenkes RI, 2016).

Sejak tahun 1995 WHO telah mengembangkan strategi penanggulangan TB dengan directly observed treatment shortcourse (DOTS), yaitu salah satu pilar pentingnya adalah pemberian obat yang tidak terputus dengan pemantauan yang erat (Kemenkes RI, 2011). Penanganan yang substandard juga akan berakibat kegagalan pengobatan, bahkan penularan kuman TB yang berkelanjutan kepada anggota keluarga dan anggota masyarakat lain serta menimbulkan resistensi obat atau dikenal dengan kasus TB-MDR (WHO, 2010).

Upaya pencegahan dan penanggulangan TB (P2TB) paru harus dilakukan secara comprehensive, integrated dan holistik. Upaya tersebut meliputi peningkatan derajat kesehatan, perlindungan khusus terhadap penyakit, penemuan kasus secara dini dan pengobatan segera, serta mencegah kefatalan dan kecacatan. Hal ini dilakukan melalui koordinasi, kerjasama dan kolaborasi dengan seluruh komponen yang ada di masyarakat, secara lintas sektoral dan lintas program. Pihak yang terlibat antara lain pemerintah (Dinas Kesehatan), kalangan akademisi, LSM, swasta. Komponen masyarakat yang menjadi mitra dalam membantu pencapaian upaya-upaya kesehatan dalam P2TB adalah adanya Kader TB, pasien TB, keluarga penderita TB dan masyarakat secara umum yang berperan aktif melalui wadah upaya kesehatan berbasis masyarakat (UKBM) pos TB desa.

Salah satu kecamatan di Kabupaten Kampar dengan jumlah TB yang terus meningkat adalah Kecamatan Kampar Kiri. Berdasarkan hasil wawancara dengan tenaga kesehatan Puskesmas Kampar Kiri, diketahui pada tahun 2016 terdapat 19 kasus TB dan pada tahun 2017 menjadi 20 kasus TB baru, serta pada Januari-Maret 2018 sudah ada tambahan 7 kasus baru. Jika dilihat dari kasus TB, masyarakat di desa-desa di Kecamatan Kampar Kiri termasuk rentan untuk menderita TB, antara lain desa Padang Sawah, Kuntu Darussalam, dan Teluk Paman. Hal ini disebabkan oleh karena masih banyaknya mitos TB, yang dipersepsikan bukan penyakit medis, tetapi penyakit yang disebabkan oleh guna-guna (dalam istilah lokal "temakan"). Sehingga hal ini menyebabkan penderita TB tidak mendapatkan pengobatan yang efektif dan adekuat, yang pada akhirnya risiko penularan dari orang ke orang semakin tinggi. Selain faktor persepsi yang keliru, perilaku masyarakat juga masih rentan untuk menimbulkan kejadian TB. 
Selanjutnya, diketahui juga bahwa salah satu penyebab tidak efektifnya pengobatan TB adalah terkait dengan belum optimalnya upaya melibatkan masyarakat secara aktif dalam membantu P2TB. Idealnya, bentuk konkrit dari keterlibataan masyarakat di desa dalam pengobatan TB adalah adanya Pos TB desa. Pos TB merupakan unit pelayanan kesehatan berbasis masyarakat dengan dukungan teknis secara lintas program dan lintas sektor. Salah satu peran penting Pos TB adalah membantu pemerintah dalam pemberdayaan masyarakat dalam P2TB paru. Beberapa penelitian telah membuktikan keberadaan Pos TB desa sangat membantu pengelolaan TB di masyarakat, antara lain penelitian Saftarina dkk. (2015) dan Pebriyanty dkk. (2017).

Berdasarkan data Puskesmas Kampar Kiri diketahui belum adanya pos TB desa. Hal ini berdampak pada masih minimnya peran masyarakat atau kader dalam membantu pengelolaan TB di Komunitas/masyarakat. Khusus untuk Desa Teluk Paman, berdasarkan hasil wawancara dengan pemegang program TB Puskesmas Kampar Kiri, belum terdapat Pos TB Desa di desa tersebut. Jika dilihat dari partisipasi masyarakat di bidang kesehatan, berdasarkan hasil wawancara dengan petugas kesehatan Puskesmas Kampar Kiri, sebenarnya partisipasi masyarakat di Desa ini cukup tinggi. Sehingga jika digerakkan, akan dapat membantu memecahkan masalah yang ada di masyarakat, termasuk membantu dalam mengelola kasus TB berbasis masyarakat.

Tujuan dari kegiatan pengabdian kepada masyarakat ini adalah: 1) Teranalisisnya situasi kebutuhan masyarakat dan pimpinan daerah (kepala desa dan jajarannya serta tokoh masyarakat) dalam pencegahan dan penanggulangan TB paru berbasis masyarakat, 2) Diperoleh dukungan pemerintah daerah setempat untuk kegiatan pemberdayaan masyarakat dalam P2TB, 3) Terbangunnya wadah UKBM Pos TB desa serta terfasilitasinya penyediaan sarana prasarana Pos TB Desa, 4) Mengembangkan jejaring untuk penguatan organisasi Pos TB desa, terutama dengan organisasi masyarakat dan tenaga kesehatan (Puskesmas), dan 5) Meningkatnya kompetensi (pengetahuan dan keterampilan) kader TB dalam membantu P2 TB paru. 6) Meningkatnya pemahaman masyarakat tentang penyakit TB serta mengetahui dan merasakan fungsi dan manfaat keberadaan Pos TB desa.

\section{MASALAH}

Terkait dengan situasi di atas, yaitu masih banyak dan tingginya risiko kasus penyakit TB yang diderita masyarakat di Desa Teluk Paman Kecamatan Kampar Kiri Kabupaten Kampar, serta belum optimalnya pemberdayaan masyarakat oleh pemerintah dan tenaga kesehatan. Selanjutnya, belum ada Pos TB Desa dan kader TB yang dapat membantu pengelolaan TB berbasis masyarakat. Berdasarkan analisis situasi tersebut, maka rumusan masalah dalam kegiatan pengabdian kepada masyarakat ini "bagaimanakah upaya pengelolaan TB paru melalui UKBM (Pos TB Desa) di Desa Teluk Paman Kecamatan Kampar Kiri Kabupaten Kampar. Lingkup kegiatan yang akan dilakukan terkait dengan upaya P2TB paru berbasis masyarakat mencakup; inisiasi pembentukan Pos TB Desa, pengembangan jejaring dalam mendukung Pos TB desa, memfasilitasi penyediaan sarana-prasarana Pos TB Desa, serta peningkatan kompetensi kader Pos TB.

\section{METODE}

Berdasarkan tujuan, rancangan kegiatan pengabdian ini terdiri dari; 1) Menganalsis situasi kejadian TB, kebutuhan dan kesiapan sumber daya manusia serta sarana prasana terkait dengan pemberdayaan masyarakat dalam P2TB. 2) Melakukan intervensi untuk memicu komitmen dan meningkatkan dukungan pemerintah desa dalam membantu terwujudnya pemberdayaan masyarakat dalam P2TB serta meningkatkan kompetensi kader (Herlina et al., 2018). Partisipan pada kegiatan ini adalah kader TB Desa, tokoh masyarakat dan petugas kesehatan, kepala desa dan staff. Jumlah kader TB pada kegiatan ini sebanyak 25 orang.

Untuk mengukur keberhasilan kegiatan, dilakukan pengumpulan data melalui wawancara, penyebaran kuesioner dan observasi. Instrumen yang digunakan adalah panduan wawancara, kuesioner, alat perekam suara dan kamera serta tabel pengumpulan data. Pengelolaan data dilakukan secara kualitatif dan kuantitatif. Untuk melihat efektivitas intervensi dilakukan uji beda, yakni membandingkan indikator sebelum dan sesudah intervensi. Uji yang digunakan adalah wilcoxon test. Kemaknaan statistik dengan nilai $\mathrm{p}<0,05$. Lokasi kegiatan adalah Desa Teluk Paman Kecamatan Kampar Kiri. Waktu kegiatan ini adalah pada tahun 2018 selama 6 bulan (Maret - Agustus). Metode intervensi dalam kegiatan ini antara lain adalah: 1) Melakukan advokasi, untuk memicu komitmen dan meningkatkan dukungan pemerintah desa dalam membantu terwujudnya pemberdayaan masyarakat dalam P2TB. 2) Bersama-sama masyarakat membentuk Pos TB Desa, 3). Melakukan pelatihan kepada kader TB dengan metode ceramah tanya jawab dan simulasi. 


\section{PEMBAHASAN}

Berdasarkan data pemegang program TB Puskesmas Kampar Kiri, diketahui bahwa pada tahun 2017 terdapat 19 kasus BTA (+) dari 77 orang suspect TB yang diperiksa. Selanjutnya, pada tahun 2018 sampai dengan bulan Juli, dari 71 orang suspect dan 59 orang yang diperiksa, jumlah pasien dengan BTA (+) adalah 21 orang. Hal ini menunjukkan terjadi peningkatan kasus dari tahun sebelumnya. Berdasarkan analisis pemegang program TB Puskesmas Kampar Kiri, permasalahan yang dihadapi antara lain; masih kurangnya penjaringan suspect TB, masih rendahnya pemeriksaan suspect TB dan kemauan masyarakat untuk pemeriksaan dini TB, penderita lalai dalam menelan obat, belum adanya kader peduli TB di setiap desa, belum tersedianya Pos TB desa dan belum optimalnya kerja sama dengan klinik swasta dalam penanganan TB. Hasil ini sejalan dengan kondisi TB di daerah lain di provinsi lain. Terkait dengan kondisi ini, Puskesmas Kampar kiri telah melakukan upaya penyelsaian masalah, antara lain upaya promotif, penemuan suspect dan kuratif (pengobatan).

Secara program, upaya P2 TB di Puskesmas Kampar Kiri secara tugas telah ada SK kepala Puskesmas kepada dua orang tenaga kesehatan sebagai pemegang program TB. Selanjutnya, berdasarkan data situasi TB di Kec Kampar Kiri, telah didiskusikan ke pimpinan Puskesmas dan pemegang program TB Puskesmas Kampar Kiri rencana kegiatan dan penyamaan persepsi untuk mencari solusi dan alternatif pemecahan masalah melalui upaya pemberdayaan masyarakat. Hasil dari kegiatan ini adalah disetujuinya perlunya upaya pemberdayaan masyarakat dalam bentuk pembentukan Pos TB desa, sekaligus menyiapkan sumberdaya manusia (Kader TB) dan sarana prasarananya. Berikut alur penemuan suspect TB di Puskesmas Kampar Kiri:

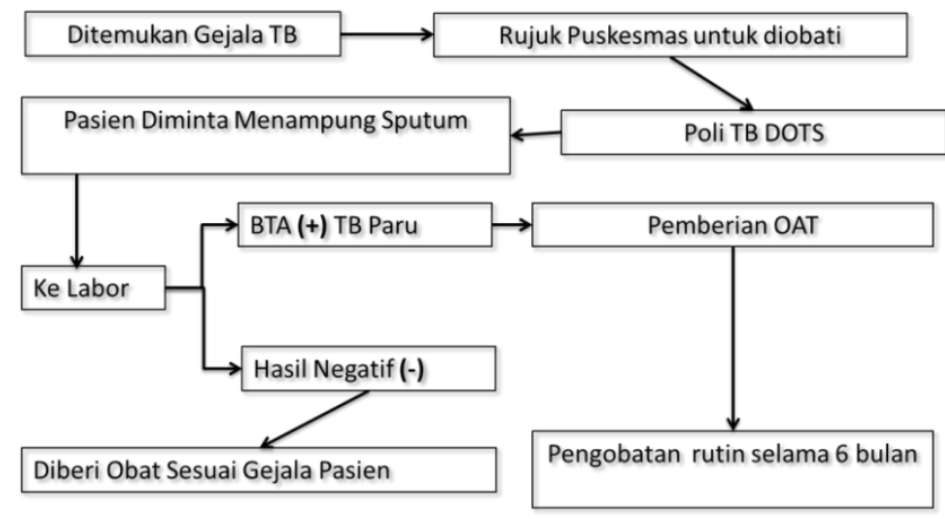

Gambar 1. Alur penemuan suspect TB di Puskesmas Kampar Kiri

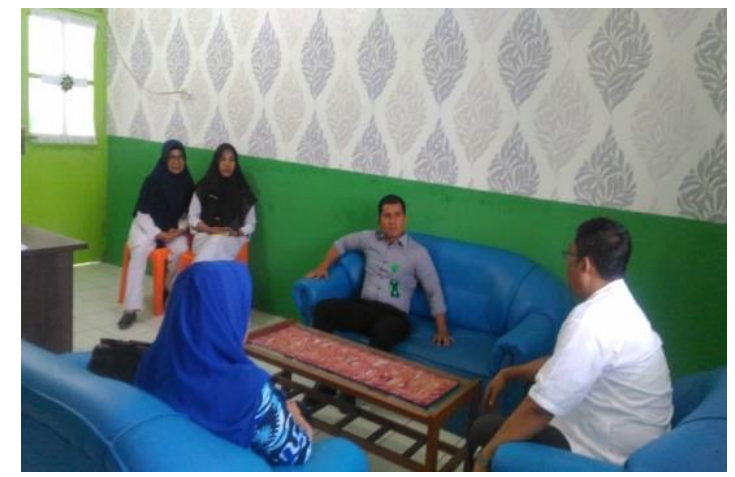

Gambar 2. Diskusi dan penyamaan persepsi untuk meningkatkan upaya pemberdayaan masyarakat dalam P2TB di Kampar Kiri

Sebagai upaya pemecahan masalah di masyarakat, telah dilakukan kegiatan pemberdayaan masyarakat dalam P2TB dengan langkah-langkah sebagai berikut:

\section{Musyawaah masyarakat desa (MMD)}

Kegiatan ini dilakukan untuk memperoleh dukungan pimpinan desa dan tokoh masyarakat terkait dengan P2TB melalui advokasi. Kegiatan advokasi ini dilakukan dalam bentuk Musyawaah masyarakat desa 
(MMD). Tujuan umum dari kegiatan MMD ini adalah untuk mendapatkan dukungan sekaligus mengkaji dan mempersiapkan pembentukan Pos TB Desa di Desa Teluk Paman Kecamatan Kampar Kiri Kabupaten Kampar. Selanjutnya, tujuan khusus MMD adalah: 1) Memaparkan situasi penyakit TB di Kecamatan Kampar Kiri dan di Desa Teluk Paman, 2) Meningkatkan pemahaman peserta MMD tentang Pos TB Desa, 3) Menginisiasi pembentukan Pos TB Desa Teluk Paman, dengan mengkaji kebutuhan dan kesiapan sumberdaya SDM (pelindung, penasehat, kader, dll), kebutuhan dan kesiapan sarana prasarana Pos TB desa, kebutuhan dan kesiapan metode untuk Pos TB Desa (kebijakan, panduan kegiatan, SOP, dll), kebutuhan dan kesiapan anggaran untuk Pos TB Desa, kebutuhan dan kesiapan pihak-pihak yang membina/kerjasama dan jejaring) untuk Pos TB Desa, dan 4) meningkatkan dukungan dan komitmen seluruh elemen masyarakat desa Teluk Paman mendirikan Pos TB Desa.

Kegiatan MMD ini telah melibatkan seluruh komponen pemerintah dan masyarakat Desa Teluk Paman, yakni Kepala Desa dan Staff, Kepala Dusun, Ketua PKK, perwakilan tokoh masyarakat/tokoh adat, ketua pemuda, perwakilan tokoh agama, kader kesehatan desa. Sebagai fasilitator pada kegiatan MMD ini adalah tenaga kesehatan Puskesmas Kampar Kiri (pemegang program TB, dan bidan/tenaga kesehatan Desa Teluk Paman), dosen tim pengabdian kepada masyarakat Fakultas Kedokteran Universitas Riau. Kegiatan MMD ini akan diadakan di Balai/aula Desa Teluk Paman. Hasil dari kegiatan ini adalah disetujuinya segera dibentuk Pos TB Desa di Teluk Paman.
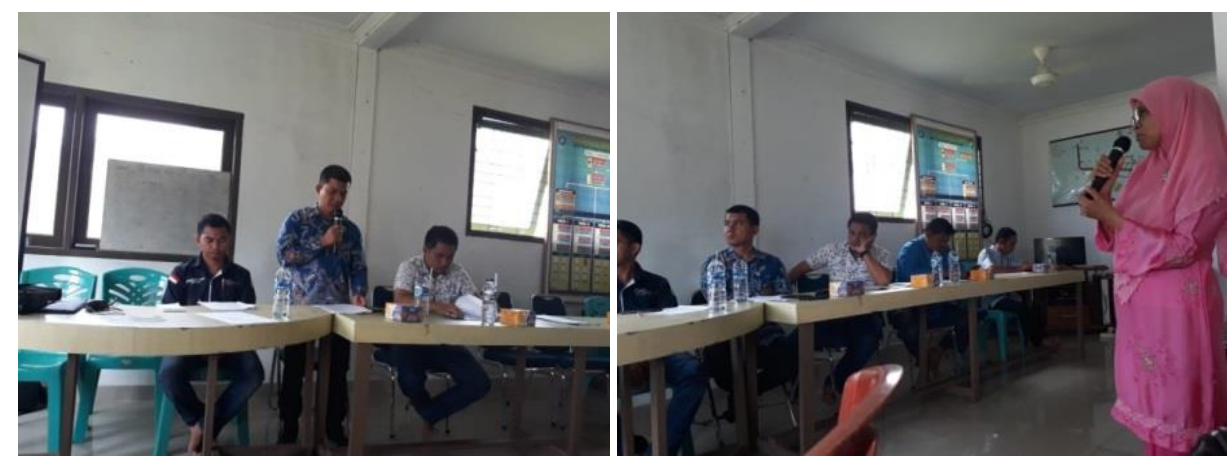

Gambar 3. Penyampaian materi pada kegiatan MMD

\section{Mendirikan Pos TB Desa}

Sebagai realisasi dari komitmen pemerintah desa dan kajian kelayakan, maka pada tanggal 15 Agustus 2018 telah didirikan Pos TB Desa di Desa Teluk Paman. Pada saat launching Pos TB di Desa Teluk Paman, dilakukan penyamaan persepsi antara Kepala Desa dan Staff, Kepala Dusun, Ketua PKK, perwakilan tokoh masyarakat/tokoh adat, ketua pemuda, perwakilan tokoh agama, kader kesehatan desa untuk bersama-sama menjadi mitra dalam mendukung dan menjalankan Pos TB di Desa Teluk Paman.

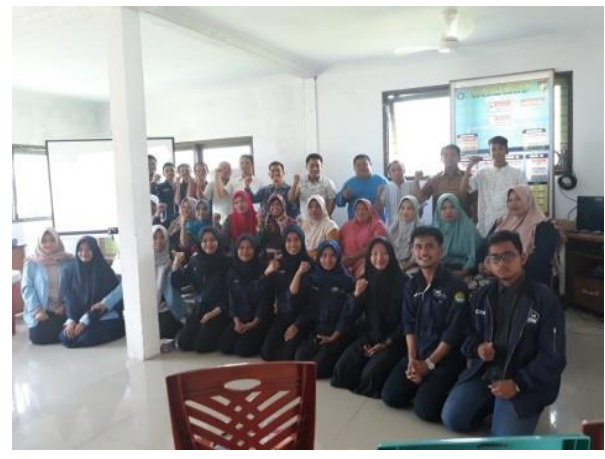

Gambar 4. Pemicuan komitmen dan dukungan untuk pendirian Pos TB Desa 


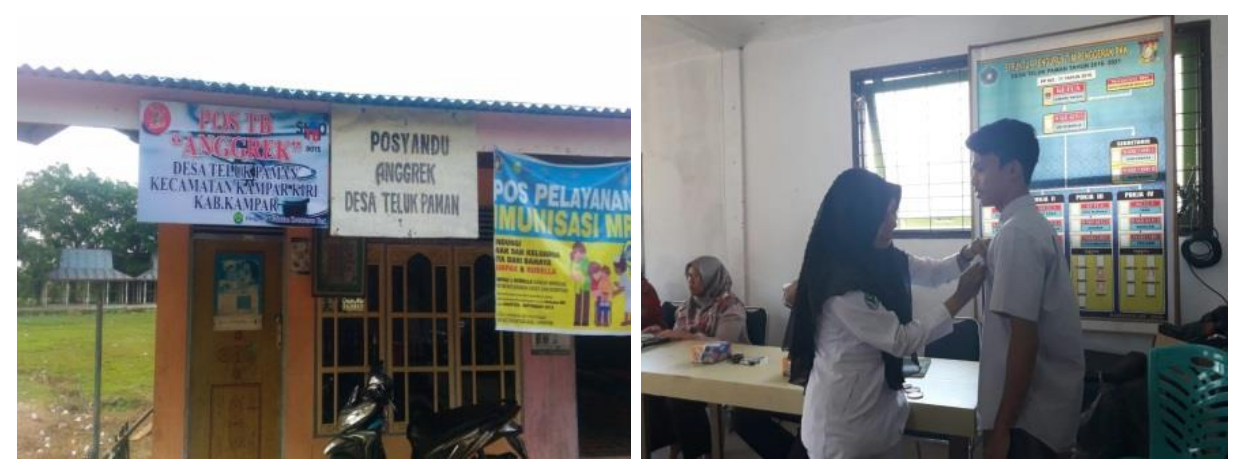

Gambar 6. Pendirian dan Pelantikan Kader Pos TB Desa

\section{Pelatihan Kader Pos TB Desa}

Dalam rangka peningkatan pemahaman kader tentang TB paru dan Pos TB Desa, telah dilakukan pelatihan kader Pos TB desa di Kecamatan Kampar Kiri Kabupaten Kampar. Kegiatan pelatihan ini telah melibatkan masyarakat yang dipilih sebagai kader TB dari 11 desa kecamatan Kampar Kiri Kabupaten Kampar sebanyak 25 peserta. Sebagai narasumber pada kegiatan ini adalah dosen tim pengabdian kepada masyarakat Fakultas Kedokteran Universitas Riau dan tenaga kesehatan Puskesmas Kampar Kiri (pemegang program TB). Karakteristik peserta pelatihan berdasarkan jenis kelamin yaitu 3 orang lakilaki dan 22 orang perempuan. Rata-rata usia peserta adalah 32 tahun dengan usia termuda 18 tahun dan usia tertua adalah 42 tahun. Peserta pelatihan berasal dari 11 desa yaitu Desa Kuntu, Teluk Paman, Teluk Paman Timur, Domo, Sungai Liti, Lipat Kain, Tanjung Mas, Lipat Kain Selatan, Lipat Kain Utara, Sungai Paku dan Sungai Harapan.

Berdasarkan pengolahan data diketahui bahwa rata-rata skor pengetahuan peserta sebelum dilakukan penyuluhan adalah sebesar 82,6 dengan standar deviasi (SD) 7,9. Berdasarkan data ini, dapat dilihat bahwa pengetahuan peserta sudah cukup baik. Setelah intervensi, diperoleh rata-rata skor pengetahuan sebesar 88,6 dengan SD 8,7. Berdasarkan hasil analisis wilcoxon test diperoleh bahwa terdapat perbedaan pengetahuan peserta yang bermakna antara sebelum dan sesudah penyuluhan dengan $p$ value 0,001 . Selanjutnya, evaluasi keberhasilan kegiatan keterampilan peserta dilakukan saat simulasi peran kader TB melalui observasi. Tim bertugas mengamati bagaimana keterampilan peserta saat simulasi/demonstrasi. Masih terdapat beberapa kekurangan skill peserta, seperti kader lupa memperkenalkan diri sebagai seorang kader TB, peserta masih ragu untuk melakukan penyuluhan kepada pasien TB, dan masih ragu untuk menentukan suspect TB. Namun, setelah simulasi selesai, semua kekurangan-kekurangan langsung diklarifikasi dan dibenarkan kembali oleh Tim Pengabdian.
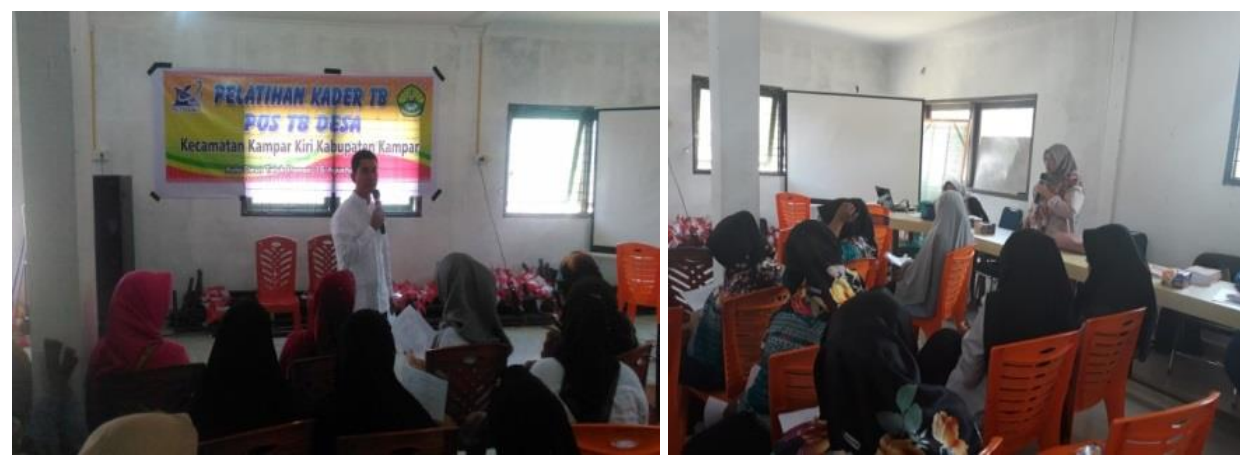

Gambar 7. Proses penyampaian materi pelatihan (ceramah) 

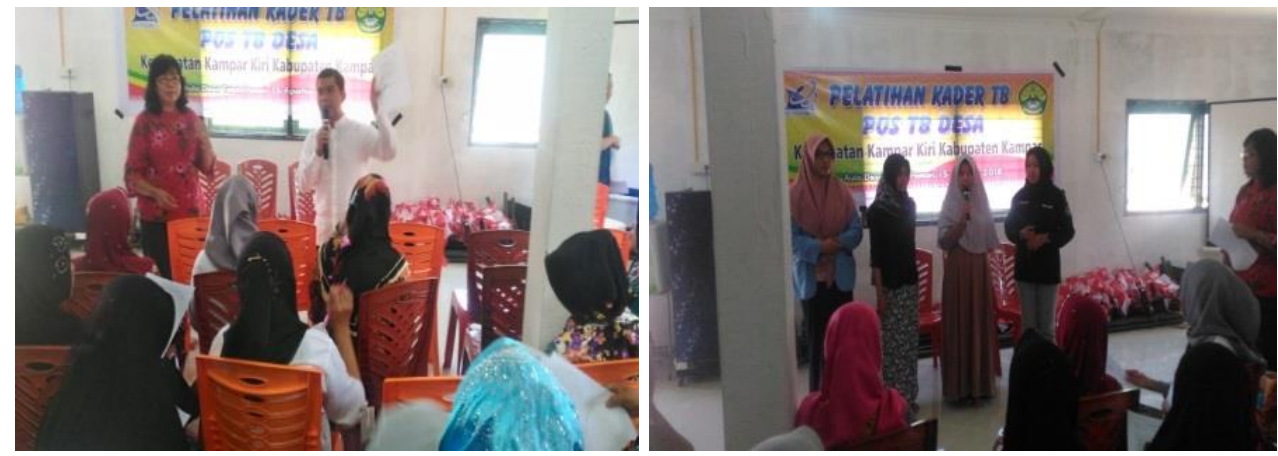

Gambar 8. Proses penyampaian materi pelatihan (simulasi)

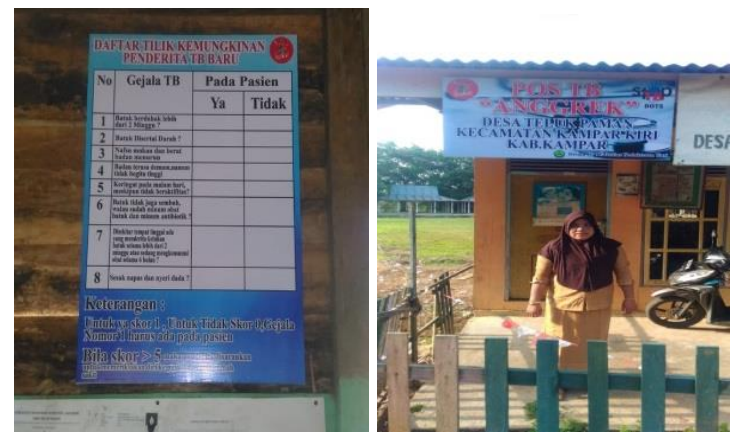

Gambar 10. Penyediaan sarana dan prasarana Pos TB Desa

\section{KESIMPULAN}

Kegiatan penelitian telah mengidentifikasi situasi pemberdayaan masyarakat dalam P2TB di Kampar Kiri masih belum optimal. Hasil intervensi advokasi yang telah dilakukan adalah telah berdirinya Pos TB desa sebagai percontohan di Desa Teluk Paman. Selanjutnya, intervensi pelatihan yang telah dilakukan dapat meingkatkan pengetahuan dan keterampilan kader dalam perannya sebagai motor penggerak Pos TB Desa.

\section{UCAPAN TERIMA KASIH}

Kami mengucapkan terima kasih yang sebesar-besarnya kepada LPPM Universitas Riau yang telah mensupport pendanaan pada kegiatan ini. Selanjutnya kepada pihak-pihak yang membantu kelancaran kegiatan antara lain; Fakultas Kedokteran Universitas Riau, UPPM Fakultas Kedokteran Universitas Riau, pimpinan Kecamatan Kampar Kiri, Kepala dan staff Puskesmas Kampar Kiri, seluruh kepala desa di Kec. Kampar Kiri, khususnya Kepala Desa Teluk Paman. tokoh masyarakat, ketua penggerak PKK Desa Teluk Paman serta kader dan masyarakat Desa Teluk Paman.

\section{DAFTAR PUSTAKA}

Burhan, E. 2010. Tuberkulosis Multi Drug Resistance (TB-MDR). Maj Kedokt Indon 60(12): 535-6.

Dinas Kesehatan Kabupaten Kampar. 2014. Profil Kesehatan Kabupaten Kampar tahun 2014. Dinas Kesehatan Kabupaten Kampar.

Dinas Kesehatan Provinsi Riau. 2015. Profil Kesehatan Provinsi Riau tahun 2015. Dinas Kesehatan Provinsi Riau.

Fauci, A. S., NIAID Tuberculosis Working Group. 2008. Multidrug-resistant and extensively drug-resistant tuberculosis: the National Institute of Allergy and Infectious Diseases Research agenda and recommendations for priority research. J Infect Dis. 197: 1493-1498.

Herlina, S., W. Winarti, \& C. Wahyudi. 2018. Meningkatkan pengetahuan dan kemampuan kader kesehatan melalui pelatihan bantuan hidup dasar. Riau Journal of Empowerment 1(2): 85-90. https://doi.org/10.31258/raje.1.2.11

Kementerian Kesehatan RI. 2011. Pedoman Nasional Penanggulangan Tuberkulosis. Jakarta: Direktorat Jendral Pengendalian Penyakit dan Penyehatan Lingkungan. 
Kementerian Kesehatan RI. 2016. Pedoman Nasional Penanggulangan Tuberkulosis. Jakarta: Direktorat Jendral Pengendalian Penyakit dan Penyehatan Lingkungan. Kementerian Kesehatan RI.

Kementerian Kesehatan RI. 2018. Rakerkesnas 2018, Kemenkes Percepat Atasi 3 Masalah Kesehatan. Diakses tanggal 8 Maret 2018. Tersedia di: http://www. depkes.go.id/article/view/18030700005/rakerkesnas-2018-kemenkespercepat-atasi-3-masalah-kesehatan.html.

Kementrian Kesehatan RI. 2014. Pedoman nasional pengendalian tuberkulosis. Kementerian Kesehatan Republik Indonesia Direktorat Jendral Pengendalian Penyakit dan Penyehatan Lingkungan: Jakarta; [Diakses tanggal 28 Februari 2017] Tersedia di: http://spiritia.or.id/dokumen/pedoman-tbnasional2014.pdf.

Pebryanty, P., T. Restuastuti, dan Zahtamal. 2017. Pengetahuan dan tindakan kader TB dalam upaya pengendalian penyakit TB paru di Kabupaten Kepulauan Meranti. JOM FK 4(2): 1-14.

Saftarina, F. Muhartono, D. W. Sumekar, dan R. Lisiswanti. 2015. Optimalisasi Peran Pos Pemberdayaan (Posdaya) dalam Peningkatan Angka Penemuan Kasus (Case Detection Rate) Tuberculosis Paru dan Pemeriksaan Basil Tahan Asam (BTA) pada Masyarakat di Kecamatan Wates, Kabupaten Lampung Tengah. JPM Ruwa Jurai. 1 (1): 21-24.

World Health Organization. 2010. Guidelines for the programmatic management of drug-resistant tuberculosis. Geneva: Emergency Updated.

World Health Organization. 2016. Global tuberculosis report 2016. World Health Organization (WHO). http://www.who.int/tb/publications/global_report/en. Diakses 28 februari 2017. 